\title{
REVIEW
}

\section{Prospects for personalizing antiviral therapy for hepatitis $C$ virus with pharmacogenetics}

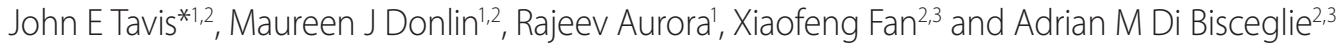

\begin{abstract}
Chronic hepatitis C virus (HCV) infection is a major cause of liver disease worldwide. HCV infection is currently treated with IFNa plus ribavirin for 24 to 48 weeks. This demanding therapy fails in up to $50 \%$ of patients, so the use of pharmacogenetic biomarkers to predict the outcome of treatment would reduce futile treatment of non-responders and help identify patients in whom therapy would be justified. Both IFNa and ribavirin primarily act by modulating the immune system of the patient, and HCV uses multiple mechanisms to counteract the antiviral effects stimulated by therapy. Therefore, response to therapy is influenced by variations in human genes governing the immune system and by differences in HCV genes that blunt antiviral immune responses. This article summarizes recent advances in understanding how host and viral genetic variation affect outcome of therapy. The most notable human associations are polymorphisms within the IL28B gene, but variations in human leukocyte antigen and cytokine genes have also been associated with treatment outcome. The most prominent viral genetic association with outcome of therapy is that HCV genotype 1 is much less sensitive to treatment than genotypes 2 and 3 , but genetic differences below the genotype level also influence outcome of therapy, presumably by modulating the ability of viral genes to blunt antiviral immune responses. Pharmacogenetic prediction of the outcome of IFN-based therapy for HCV will require integrating the efficacies of the immunosuppressive mechanisms of a viral isolate, and then interpreting the viral resistance potential in context of the genetic profile of the patient at loci associated with outcome of therapy. Directacting inhibitors of HCV that will be used in combination with IFNa are nearing approval, so genetic prediction for anti-HCV therapy will soon need to incorporate viral genetic markers of viral resistance to the new drugs.
\end{abstract}

\section{Hepatitis C: the disease, the virus and the therapy} Up to 170 million people worldwide are chronically infected with hepatitis $\mathrm{C}$ virus (HCV) [1]. Chronic HCV infection is asymptomatic or associated with relatively mild hepatitis in most individuals. However, about $20 \%$ of patients have progressive hepatitis, where disease proceeds from hepatitis of gradually worsening severity, through increasing hepatic fibrosis and cirrhosis, and eventually terminating in fatal liver failure or hepatocellular carcinoma [2]. The rate of progression along this path varies from a few years in exceptionally rapid progressors to many decades in slow progressors, with relatively slow progression being the norm.

$\mathrm{HCV}$ is a hepatotropic flavivirus in the Hepacivirus genus. The enveloped virion contains a positive-polarity

\footnotetext{
*Correspondence: tavisje@slu.edu
}

'Department of Molecular Microbiology and Immunology, Saint Louis University School of Medicine, Saint Louis, MO 63104, USA

Full list of author information is available at the end of the article
RNA genome that is about 9,600 nucleotides long and encodes a polyprotein of roughly 3,000 amino acids. Cleavage of the polyprotein produces three structural proteins (core, E1 and E2) and seven non-structural proteins (P7, NS2, NS3, NS4A, NS4B, NS5A and NS5B). The HCV genome is genetically very variable, with six genotypes that are less than $72 \%$ genetically identical, and over 100 subtypes with identities of $75 \%$ to $86 \%$ [3]. Genotype 1 accounts for about $75 \%$ of the HCV isolates in the USA; almost all are subtype 1a or 1b. Independent $\mathrm{HCV}$ isolates of a given subtype typically differ by $6 \%$ to $10 \%$, and genetic variation between viral genomes within an individual is usually $1 \%$ to $3 \%$ because of the replication of $\mathrm{HCV}$ as a quasispecies (that is, a collection of genetic variants that clusters around a master sequence and that evolves as a unit [4]).

$\mathrm{HCV}$ infection is currently treated with a combination of pegylated IFN $\alpha$ and ribavirin. Treatment eliminates the virus (sustained viral response, SVR) in $50 \%$ to $60 \%$ of genotype 1 patients [5]. Treatment typically lasts for 48 weeks, but it is discontinued if viremia is present at 24 weeks because the chances of achieving SVR are 
negligible if the virus is detectable at this time. There are two major drawbacks to this therapy beyond its limited efficacy. First, IFN $\alpha$ causes severe side-effects, including flu-like illness, depression, anorexia, anemia and lymphopenia, and these problems are exacerbated by ribavirin $[6,7]$. The risk of these complications is high enough that many patients are ineligible for treatment. Treatment therefore requires supervision by a skilled medical team, and even then a third of patients can be incapable of taking the full regimen without dose reductions. Second, therapy can cost over US $\$ 40,000$ per patient [8], and hence it is unaffordable for many patients.

Numerous direct-acting inhibitors of the enzymes of HCV are under development [9-11], and two NS3 protease inhibitors are likely to be approved in 2011. However, all direct-acting inhibitors of $\mathrm{HCV}$ are plagued by very rapid development of resistance due to the high genetic diversity and rapid evolution of $\mathrm{HCV}$, and hence the new drugs will be used in combination with IFN $\alpha$ and ribavirin for the foreseeable future [12].

Here, we review recent advances in our knowledge concerning the host and viral genetic variables that affect outcome of therapy.

\section{Roles of IFNa and ribavirin during therapy}

IFN $\alpha$ provides the primary antiviral effect and can clear $\mathrm{HCV}$ when used alone, whereas ribavirin is ineffective by itself but roughly doubles the viral clearance rate when taken with IFN $[5,13]$. The mechanisms by which IFN $\alpha$ and ribavirin suppress HCV are incompletely understood, but each drug clearly acts through multiple mechanisms. IFN $\alpha$ triggers the type 1 IFN response and stimulates adaptive immune responses to the virus, but the details of how these cellular responses control $\mathrm{HCV}$ are largely unknown. Ribavirin may act by skewing host immunity towards a Th1-type response, amplifying the type 1 IFN response, suppressing cellular guanosine triphosphate pools, and/or interfering with the fidelity of $\mathrm{HCV}$ replication. Importantly, all of these antiviral pressures are mediated by cellular effectors, with the exception of the potential impact of ribavirin on the viral RNA polymerase.

\section{Host and viral genetic variation both affect outcome of therapy}

The outcome of IFN-based therapy for HCV is dependent on the genetic systems of both the human host and the virus. Host genetic factors that influence the outcome of therapy include gender, race and variation in genes of the immune system. The primary viral genetic factor is the HCV genotype because some genotypes are more sensitive to IFN than others, but other aspects of viral variability are also important. The major host and viral genetic factors affecting outcome of therapy are summarized in Figure 1.
The human immune responses to $\mathrm{HCV}$ and the countermeasures of the virus are directly relevant to antiviral therapy because the dominant drug in therapy is IFN $\alpha$, which is a key cytokine in the type 1 IFN response. The replication of $\mathrm{HCV}$ replication triggers innate immune pressures, and then the virus counters these immune responses with an array of immunosuppressive strategies to promote its persistence $[14,15]$. The best understood immunosuppressive strategies include inhibition of protein kinase R (PKR) by the viral NS5A and E2 proteins, cleavage of cellular signal transduction molecules downstream of the pathogen RNA sensors RIG-I and TLR3 by the NS3/4A protein, and altering IL12 production through secretion of the core protein; other less thoroughly characterized suppressive activities also exist.

Accurate prediction of the outcome of therapy would reduce complications associated with futile treatment while simultaneously increasing the number of potential responders who receive therapy. The pleiotropic pressures applied against HCV by IFN-based therapy have two key implications on pharmacogenetic personalization of treatment for HCV. First, the role of the immune system in pharmacological control of HCV indicates that human genetic polymorphisms affecting these pathways could modulate efficacy of therapy. Second, viral resistance to IFN-based therapies will be proportional to the net effect of the multiple immunosuppressive activities of HCV. Therefore, predicting the outcome of therapy will require integrating the efficacies of the immunosuppressive mechanisms of a given $\mathrm{HCV}$ isolate, and then interpreting the viral resistance potential in context of the genetic profile of the patient at loci associated with outcome of treatment.

\section{Host genetic associations with outcome of therapy}

The dominant role of the immunomodulator IFN $\alpha$ in treating $\mathrm{HCV}$ infection has driven an extensive search for genetic associations between components of the immune system and outcome of therapy [16-18] (Table 1). Many studies have focused on the human leukocyte antigen class I and II genes, and most, but not all, studies have found associations between particular alleles and outcome of IFN-based therapy. However, there is little overlap in the alleles identified by the various groups. Genetic associations with outcome of therapy have also been reported for the genes encoding KIR2DL5, IL6, IL10, IL12B, CCL5, TGF $\beta$, TNF $\alpha$, IFN $\gamma$, osteopontin, GNB3, and CTLA4. However, other studies have failed to find associations with many of these genes. The inconsistencies in these data appear to be due to differences among the studies in the racial make-up and HIV co-infection status of the cohorts, the definition of therapeutic response, the therapy employed (IFN $\alpha$ monotherapy, IFN plus ribavirin, or 


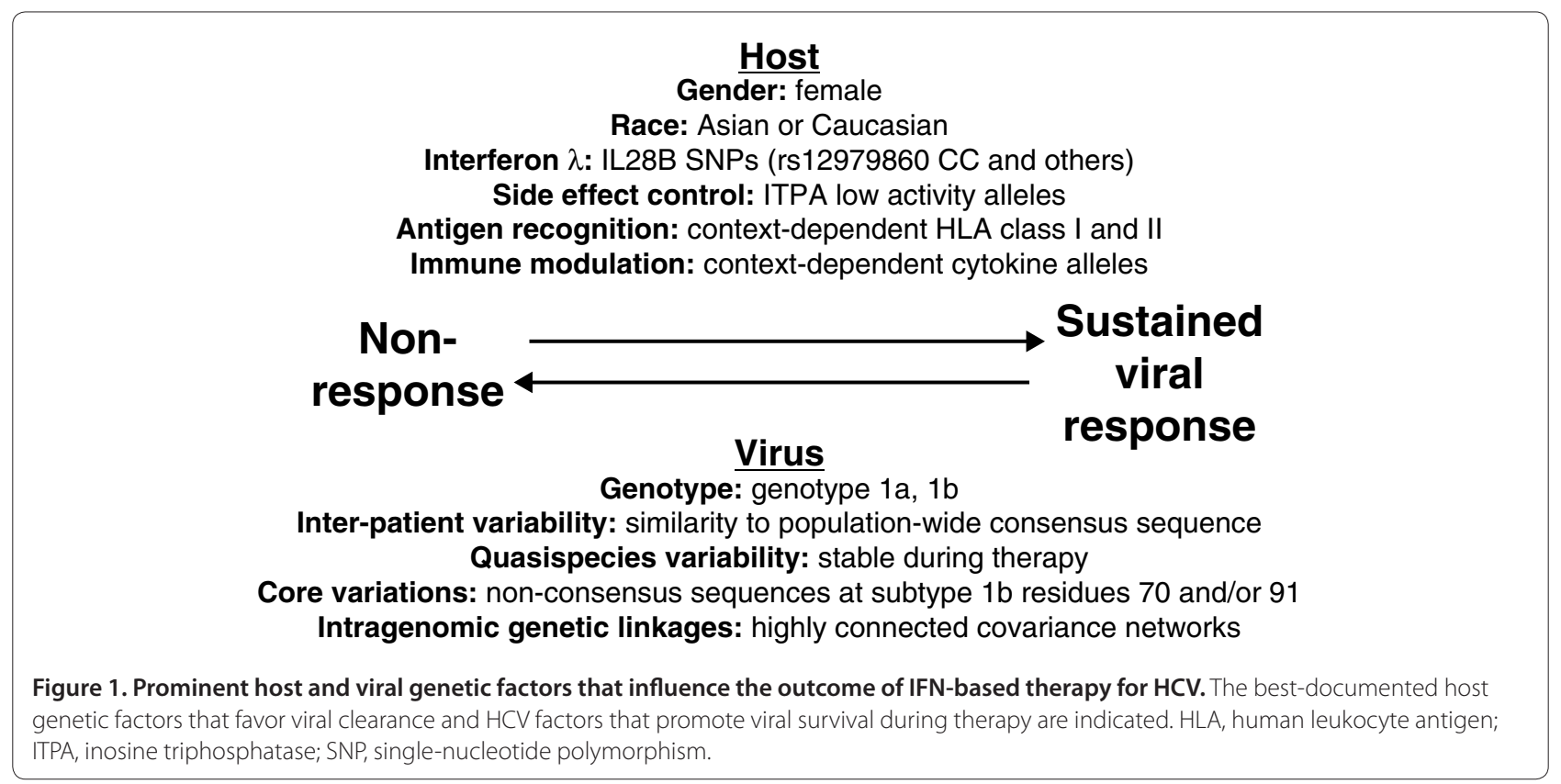

pegylated IFN plus ribavirin), and the $\mathrm{HCV}$ genotype infecting the study participants. Together, these data clearly demonstrate that polymorphisms in immune system genes can strongly influence the outcome of antiHCV therapy, but these associations appear to be context dependent, and hence are unlikely to be broadly useful in predicting treatment outcome.

A breakthrough in understanding human genetic associations with outcome of therapy occurred in 2009 when three seminal genome-wide association studies demonstrated that polymorphisms near the IL28B gene, which encodes IFN $\lambda 3$ [19], were strongly associated with treatment outcome for HCV genotype 1 [20-22]. The strongest association was found for SNP rs12979860, located about $3 \mathrm{~kb}$ upstream of the $I L 28 B$ coding region. Patients with a $\mathrm{CC}$ genotype at this SNP were more than twice as likely to achieve SVR as patients with a CT or TT genotype [20]. The three studies each identified different SNPs near $I L 28 B$, but the underlying biological association with treatment outcome appears to be the same because there is a strong linkage disequilibrium among these SNPs. Suppiah et al. [21] estimated that the cumulative effect of the favorable allele at the IL28B locus is to increase SVR by $32 \%$ relative to a population in which the allele is absent (population attributable risk). The favorable association of the CC genotype was found in patients of both European and African-American descent, and differential prevalence of the $\mathrm{CC}$ genotype explained approximately half of the twofold poorer response rate to treatment found in African Americans [20,23].

The effect of variation at r12979860 with HCV treatment outcome has been validated in a new cohort that included 186 genotype 1 and 45 genotype 2 or 3 patients [24]. The r12979860 SNP has also been associated with more rapid decline of viral titers during therapy and with end-of-treatment response [25]. An association of the CC genotype at the r12979860 SNP with SVR is also found in patients infected with the easier-to-treat HCV genotypes 2 or 3, but only in patients who do not have a rapid early decline in HCV titers [26]. The association of IL28B polymorphisms and response to treatment also appears to hold in patients that are co-infected with HIV [27-29]. A similar association of polymorphisms in the $I L 28 B$ r12979860 SNP is found with spontaneous clearance of acute genotype $1 \mathrm{HCV}$ infection [30-32], and with a different SNP for patients infected with genotype 1 or 4 for both spontaneous clearance and response to therapy [33].

The IL28B gene encodes the type 3 IFN, IFN $\lambda$ [19]. IFN $\lambda$ has been shown to inhibit HCV replication [34], so the variations in the $I L 28 B$ gene mutations presumably affect the efficacy of the innate immune response against HCV during therapy. Regardless of mechanism, the very strong association of the $I L 28 B$ polymorphisms with outcome of IFN-based therapy has already led to clinical genetic tests to help guide antiviral treatment.

The association of human SNPs with ribavirin-induced reduction in hemoglobin levels has also been assessed [35] because treatment-induced hemolytic anemia is one of the most serious side-effects of IFN-based therapy [7]. This does not directly address treatment outcome, but anemia often causes dose reductions that lower treatment efficacy. Genotypes of SNPs rs1127354 and rs7270101 within the inosine triphosphatase gene that decrease the activity of the enzyme have been found to be strongly 
Table 1. Host genetic factors that affect treatment outcome

\begin{tabular}{|c|c|c|c|c|}
\hline Gene symbol & Gene name/description & Polymorphism & Effect on treatment & Reference(s) \\
\hline \multicolumn{5}{|l|}{ IFN $\lambda$} \\
\hline IL28B & Interferon, $\lambda 3$ & SNP rs12979860 (C/C) & Twofold increased rate of SVR & [20] \\
\hline IL28B & Interferon, $\lambda 3$ & $\begin{array}{l}\text { SNPs rs } 8099917(G) \\
\text { and rs } 12980275\end{array}$ & Associated with non-response & [22] \\
\hline IL28B & Interferon, $\lambda 3$ & SNP rs809917 (T) & Twofold increased rate of SVR & [21] \\
\hline \multicolumn{5}{|l|}{ Side-effect modulator } \\
\hline ITPA & Inosine triphosphatase & $\begin{array}{l}\text { SNPs rs } 1127354 \text { (A) } \\
\text { and rs7270101 (C) }\end{array}$ & $\begin{array}{l}\text { Increased protection against } \\
\text { ribavirin-induced anemia }\end{array}$ & [35-38] \\
\hline \multicolumn{5}{|l|}{ HLA alleles } \\
\hline HLA-A24-B54-DR4 & HLA class I/II haplotype & NA & Associated with non-response & [73] \\
\hline HLA-B54 & HLA class I allele & NA & Associated with non-response & [73] \\
\hline HLA-DRB $1 * 0404$ & HLA class II allele & NA & Associated with response & [74] \\
\hline$H L A-D R B 1 * 0701,-D R A 1^{*} 0201,-D Q B 1 * 02$ & HLA class II haplotype & NA & Associated with response & [75] \\
\hline HLA-A11, -B51, -CW5 and -DRB1*15 & HLA class I and II alleles & NA & Associated with response & [76] \\
\hline HLA-A24 & HLA class I allele & NA & Associated with non-response & [76] \\
\hline HLA-DRB 1*04 & HLA class II allele & NA & $\begin{array}{l}\text { Associated with non-response } \\
\text { to IFN monotherapy }\end{array}$ & [77] \\
\hline HLA-DRB 1*07 & HLA class II allele & NA & Associated with response & [78] \\
\hline HLA-A33 & HLA class I allele & NA & Associated with response & [79] \\
\hline$H L A-D R B 1^{*} 07$ & HLA class II allele & NA & Associated with non-response & [80] \\
\hline HLA-DRB1*11, -DRB1*0301 & HLA class II alleles & NA & Associated with response & [80] \\
\hline HLA-A24, -B40-B46 & HLA class II alleles & NA & Associated with response & [81] \\
\hline \multicolumn{5}{|l|}{ Other immune-related genes } \\
\hline KIR2DL5 & $\begin{array}{l}\text { Killer cell immunoglobulin- } \\
\text { like receptor }\end{array}$ & NA & Associated with non-response & [82] \\
\hline $1 L 6$ & Interleukin 6 & IL6 C174G & Associated with response & [83] \\
\hline IL10 & Interleukin 10 & IL10 -592A and -819T & Associated with response & {$[84,85]$} \\
\hline IL12B & Interleukin 2B & IL12B 3'-UTR 1188C & Associated with response & [86] \\
\hline$M X A$ & Interferon-inducible protein & MXA $-88 G$ and $-123 A$ & Response to IFN monotherapy & [87] \\
\hline CCR5 & Chemokine receptor 5 & CCR5 - $\triangle 32$ & $\begin{array}{l}\text { Associated with non-response to } \\
\text { IFN monotherapy }\end{array}$ & [88] \\
\hline CCL5 & Chemokine ligand 5, RANTES & $\begin{array}{l}\text { CCL5 Int } 1.1 C \text { and } \\
3^{\prime} 222 C\end{array}$ & Associated with non-response & [89] \\
\hline TGF $\beta$ & Transforming growth factor $\beta$ & $\begin{array}{l}\text { TGF } \beta 10 \mathrm{10T} / \mathrm{T}, 25 \mathrm{G} / \mathrm{G} \\
\text { and } 10 \mathrm{~T} / \mathrm{C}, 25 \mathrm{G} / \mathrm{G}\end{array}$ & $\begin{array}{l}\text { High producer TGF } \beta \text { genotype } \\
\text { associated with response }\end{array}$ & [90] \\
\hline$T N F a$ & Tumor necrosis factor a & TNFa $-308 \mathrm{~A}$ & Associated with response & [91] \\
\hline IFNY & Interferon $\gamma$ & IFNY-764G & Associated with response & [92] \\
\hline OPN & Osteopontin & OPN $-1748 \mathrm{G} / \mathrm{G}$ or $\mathrm{G} / \mathrm{A}$ & & \\
\hline OPN $-443 \mathrm{~T} / \mathrm{T}$ & Associated with response & [93] & & \\
\hline GNB3 & $\begin{array}{l}\text { Guanine nucleotide-binding } \\
\text { protein } \beta \text { polypeptide } 3\end{array}$ & GNB3 825 C/C & Associated with non-response & {$[94,95]$} \\
\hline CTLA4 & $\begin{array}{l}\text { Cytotoxic T-lymphocyte } \\
\text { associated protein, T-cell } \\
\text { inhibition }\end{array}$ & $\begin{array}{l}\text { CTLA4 -318C -49G } \\
\text { haplotype }\end{array}$ & Associated with response & {$[96,97]$} \\
\hline
\end{tabular}

HLA, human leukocyte antigen; IFN, interferon; NA, not applicable; SNP, single-nucleotide polymorphism; SVR, sustained viral response; UTR, untranslated region.

associated with protection against anemia [35]. These results were confirmed in an independent cohort of western patients [36]. Two additional studies confirmed the association of rs1127354, but not rs7270101, with 
ribavirin-induced anemia in Japanese patients infected with HCV genotype 1b [37,38]. Sakamoto et al. [37] also found that patients with the favorable inosine triphosphatase allele have a higher rate of SVR, which they attribute to better adherence to therapy.

\section{Viral genetic associations with outcome of IFN-based therapy}

The clearest indication that the high genetic variation of $\mathrm{HCV}$ affects outcome of therapy is that patients infected with genotype 1 achieve SVR about $50 \%$ of the time following 48 weeks of therapy, whereas patients with genotypes 2 and 3 achieve SVR with frequencies $>80 \%$ after only 24 weeks of treatment [5]. HCV genotype is therefore a key parameter in deciding whether to initiate treatment, with a higher proportion of patients infected with genotype 2 and 3 being eligible for treatment.

A fundamental aspect of the biology of $\mathrm{HCV}$ is its replication as a quasispecies. The influence of quasispecies diversity/complexity on efficiency of antiviral therapy has been extensively explored, with conflicting results. Better responses have been linked to low pretreatment quasispecies diversity/complexity in most studies [39-42] but not in others [43,44]. The reasons for this discrepancy are not fully understood. In contrast, a rapid shift of the quasispecies spectrum early during treatment is clearly associated with better response $[45,46]$. In an attempt to clarify the role of HCV quasispecies variation in viral sensitivity to IFN-based therapy, we evaluated the association of baseline HCV quasispecies diversity/complexity in the hypervariable region 1 of the E2 protein with response to therapy in $153 \mathrm{HCV}$ genotype 1 patients and found that quasispecies diversity/ complexity can affect the outcome of therapy, but that this effect may become apparent only when the diversity/ complexity rises above a critical point [47].

Variations in the quasispecies master sequence (defined in practical terms as the consensus HCV sequence within a patient) between individuals have also been associated with outcome of therapy. The first such observation was that the number of variations in subtype $1 \mathrm{~b}$ amino acid residues 2209 to 2248 (the 'interferon sensitivity determining region', ISDR) relative to $\mathrm{HCV}$ strain J was correlated with response to IFN-based therapy [48]. The ISDR is part of a PKR-binding site [15], and consequently this association is based on a reasonable mechanism: differential inhibition of PKR activity by variant $\mathrm{HCV}$ genomes. The association of variability in the ISDR with non-response has been consistently found in Japanese patients infected with subtype $1 \mathrm{~b}$, but is weak in other contexts $[49,50]$. The sequence at the ISDR remains an independent predictor of outcome for Japanese genotype $1 \mathrm{~b}$ patients even when normalized for the effect of $I L 28 B$ polymorphisms [51,52].
Variation at HCV core protein positions 70 and/or 91 relative to the prototype sequences of R70 and L90 has been repeatedly associated with non-response to IFNbased therapy in Japanese genotype 1b patients [53-55], but in not in genotype 2a patients [56]. Variation at core residues 70 and/or 91 in HCV $1 \mathrm{~b}$ patients has remained a predictor of treatment outcome in multivariate models including the $I L 28 B$ polymorphisms [57] and during triple therapy including IFN, ribavirin and one of the promising NS3 protease inhibitors [58].

Similarly, genetic variation at a PKR-binding site in the viral E2 protein, termed the PePHD, has been associated with response to therapy in a few studies $[59,60]$, but not in most $[61,62]$.

This association of low viral genetic diversity relative to the population-wide consensus sequence with poor response to therapy implies that viral sequences with low diversity are closest to an optimal sequence and hence have the greatest IFN-resistance potential. In this context, resistance can be impaired by variations at many different sites throughout the viral genome. However, results from the various $\mathrm{HCV}$ genetic studies have often been incompletely reproducible, possibly due to complementation between the multiple immunosuppressive activities of HCV that would not have been evident in analysis of individual viral genes. This appears to be the case because analysis of the full HCV coding potential revealed that the viral genomes in responders to IFNbased therapy are much more diverse than genomes from non-responders, that these diversity differences are concentrated in genes with known immunosuppressive activities (especially the core, E2, NS3 and NS5A genes), and that an individual isolate may not necessarily have the same diversity pattern at all of these genes [63-65]. Our very rough estimate is that differences in $\mathrm{HCV}$ genetic diversity among infected individuals may account for about $30 \%$ of the treatment failures [65]; this fraction is similar to that contributed by variation in the human IL28B locus [21].

The potential for intragenomic complementation is emphasized by the recently discovered genome-wide huband-spoke networks of amino acid covariances in $\mathrm{HCV}$ $[66,67]$. The structure of these networks indicates that the viral genome functions as an integrated unit. Therefore, we asked whether the networks could improve prediction of therapeutic efficacy through their ability to integrate information across the viral genome. The covariance networks were found to be very different in sequences from responders and non-responders to IFN-based therapy, and differences in the networks could help predict outcome of therapy in this set of samples [66]. This result has not been independently confirmed because there are no other publicly available full-ORF HCV sequences from patients for whom the outcome of IFN-based therapy is known. 


\section{Impact of the new direct-acting drugs on pharmacogenetic tailoring of therapy}

Antiviral therapy for $\mathrm{HCV}$ will change dramatically in the near future as direct-acting antiviral drugs targeting the viral protease and RNA polymerase activities become available [9-11]. These compounds cannot be used as monotherapies because resistance develops within weeks when they are used alone [12,68-70], so at least the first generation of direct-acting drugs will be used in combination with IFN $\alpha$ and ribavirin. Therefore, pharmacogenetic personalization of $\mathrm{HCV}$ therapy will soon add assessment of viral resistance mutations to the directacting agents to evaluation of host and viral markers of IFN efficacy. Evaluation of the resistance markers will be similar to what is currently done for HIV and hepatitis B virus [71,72]. As the anti-HCV pharmacological toolbox increases, the viral markers governing efficacy of the direct-acting antivirals will become progressively more important for guiding the choice of drugs to be employed. Eventually, a cocktail of direct-acting compounds is expected to eliminate the need for IFN entirely. When this happens, the role of host immunological polymorphisms and immunosuppressive genetic patterns of $\mathrm{HCV}$ in predicting therapeutic efficacy will be supplanted by assessment of viral variables that define the sensitivity of a given $\mathrm{HCV}$ isolate to the drugs. A role for host markers in guiding therapy may persist, but it will be limited to evaluation of sensitivity to side-effects of the drugs. Although many promising anti-HCV drugs are in the pipeline, it is impossible to predict when IFN will be supplanted, and so pharmacogenetic prediction of the response of $\mathrm{HCV}$ to therapy will remain a dynamic field for the foreseeable future.

\section{Conclusions}

$\mathrm{HCV}$ infections are a leading cause of liver disease and liver cancer worldwide. HCV infection is treated with IFN $\alpha$ plus ribavirin, but this expensive, year-long therapy is plagued with severe side-effects and it clears the virus in only about half of patients. Response of HCV to IFNbased therapy is affected by variations in human genes controlling antiviral immune responses and by differences in $\mathrm{HCV}$ genes that suppress these immune responses. The most prominent human genetic associations with outcome of therapy are polymorphisms within the $I L 28 B$ gene, but associations with variations in the human leukocyte antigen and cytokine genes also exist. Obtaining a molecular understanding of the mechanisms by which these genetic associations modulate the outcome of therapy would substantially improve therapy. The most obvious viral genetic association is that $\mathrm{HCV}$ genotype 1 is less sensitive to treatment than are genotypes 2 and 3, but genetic differences at the isolate and quasispecies levels also affect outcome of therapy.
Understanding the mechanisms underlying these viral genetic associations would also improve therapeutic options for HCV patients. The contribution of both host and viral genetic variations in determining the outcome of therapy indicates that predicting the outcome of therapy for $\mathrm{HCV}$ will require integrating the efficacies of the immunosuppressive mechanisms of a viral isolate, and then interpreting the viral resistance potential in context of the genetic profile of the patient at genes associated with outcome of therapy. Reaching this goal will require a deeper understanding than is currently available of the human and viral genetic associations with response to therapy and of how these genetic variations interact with each other. Anti-HCV therapy is expected to change dramatically in the near future with the approval of direct-acting inhibitors of viral proteins, so outcome prediction will soon need to incorporate viral genetic markers of the resistance of $\mathrm{HCV}$ to the new drugs. This will require detailed viral genetic analyses to identify clinically relevant resistance mutations and their cross-resistance characteristics. Eventually the directacting drugs are expected to eliminate the need for IFN and ribavirin. At this time, evaluation of human genetic markers of immunological efficacy and viral markers of immunosuppressive potential will be supplanted by assessment of viral biomarkers of drug sensitivity.

\section{Abbreviations}

CCL5, chemokine (CC motif) ligand 5; CTLA, cytotoxic T-lymphocyte antigen 4; GNB3, guanine nucleotide-binding protein $\beta$ polypeptide 3; HCV, hepatitis C virus; IFN, interferon; IL, interleukin; ISDR, interferon sensitivity determining region; ORF, open reading frame; PKR, protein kinase $R$; $S N P$, single-nucleotide polymorphism; SVR, sustained viral response; TGF, transforming growth factor; TNF, tumor necrosis factor.

\section{Competing interests}

JT, RA and MD are co-inventors on pending patent applications covering the use of covariance network analysis to predict the outcome of antiviral therapy. No other competing interests exist.

\section{Authors' contributions}

JT coordinated the literature review and wrote the majority of the manuscript. $\mathrm{MD}$ and XF conducted primary literature searches and wrote the relevant sections of the text. RA and ADB contributed to the choice of topics covered in this article and evaluated its clinical and scientific accuracy. All authors read and approved the final manuscript.

\section{Authors' information}

JT is a Professor of Molecular Virology at Saint Louis University School of Medicine, and has expertise in hepatitis B virus replication and hepatitis C virus genetics. MD is a Research Associate Professor at Saint Louis University School of Medicine who specializes in bioinformatics. RA is an Associate Professor of Systems Biology at Saint Louis University School of Medicine, and has expertise in molecular biology and network analysis. XF is an Associate Professor of Molecular Virology at Saint Louis University who has expertise in HCV genetics. ADB is the Chair of Medicine at Saint Louis University, and has clinical and scientific expertise in viral hepatitis.

\section{Acknowledgements}

Compilation of this review was supported by Saint Louis University institutional funds. 


\section{Author details}

'Department of Molecular Microbiology and Immunology, Saint Louis University School of Medicine, Saint Louis, MO 63104, USA. '2Saint Louis University Liver Center, Saint Louis University School of Medicine, Saint Louis, MO 63104, USA. ${ }^{3}$ Department of Medicine, Saint Louis University School of Medicine, Saint Louis, MO 63104, USA.

Published: 8 February 2011

\section{References}

1. Lemon SM, Walker C, Alter MJ, Yi M: Hepatitis C virus. In Fields Virology. 5th edition. Edited by Knipe DM, Howley P, Griffin DE, Lamb RA, Martin MA, Roizman B, Straus SE. Philadelphia: Lippincott Williams and Wilkins; 2007:1253-1304.

2. Thomas DL, Seeff LB: Natural history of hepatitis C. Clin Liver Dis 2005, 9:383-398, vi.

3. Simmonds P: Genetic diversity and evolution of hepatitis $C$ virus - 15 years on. J Gen Virol 2004, 85:3173-3188.

4. Lauring AS, Andino R: Quasispecies theory and the behavior of RNA viruses. PLoS Pathog 2010, 6:e1001005.

5. Feld JJ, Hoofnagle $\mathrm{JH}$ : Mechanism of action of interferon and ribavirin in treatment of hepatitis C. Nature 2005, 436:967-972

6. Younossi Z, Kallman J, Kincaid J: The effects of HCV infection and management on health-related quality of life. Hepatology 2007, 45:806-816

7. Sulkowski MS: Anemia in the treatment of hepatitis $C$ virus infection. Clin Infect Dis 2003, 37 Suppl 4:S315-S322.

8. McHutchison JG, Bacon BR, Owens GS: Making it happen: managed care considerations in vanquishing hepatitis C. Am J Manag Care 2007, 13 Suppl 12:S327-S336.

9. Thompson AJ, McHutchison JG: Antiviral resistance and specifically targeted therapy for HCV (STAT-C). J Viral Hepat 2009, 16:377-387.

10. Lemon SM, McKeating JA, Pietschmann T, Frick DN, Glenn JS, Tellinghuisen TL, Symons J, Furman PA: Development of novel therapies for hepatitis $C$ Antiviral Res 2010, 86:79-92.

11. Enomoto $M$, Tamori A, Kawada N: Emerging antiviral drugs for hepatitis $C$ virus. Rev Recent Clin Trials 2009, 4:179-184.

12. Kieffer $T L$, Kwong $A D$, Picchio GR: Viral resistance to specifically targeted antiviral therapies for hepatitis C (STAT-CS). J Antimicrob Chemother 2010, 65:202-212

13. Chevaliez S, Pawlotsky JM: Hepatitis C virus: virology, diagnosis and management of antiviral therapy. World J Gastroenterol 2007, 13:2461-2466.

14. Rehermann B, Nascimbeni M: Immunology of hepatitis B virus and hepatitis C virus infection. Nat Rev Immunol 2005, 5:215-229.

15. Gale M, Jr., Blakely CM, Kwieciszewski B, Tan SL, Dossett M, Tang NM, Korth MJ, Polyak SJ, Gretch DR, Katze MG: Control of PKR protein kinase by hepatitis C virus nonstructural $5 \mathrm{~A}$ protein: molecular mechanisms of kinase regulation. Mol Cell Biol 1998, 18:5208-5218.

16. Nattermann J, Leifeld L, Spengler U: Host genetic factors and treatment of hepatitis C. Curr Mol Pharmacol 2008, 1:171-180.

17. Yee $L$ J: Host genetic determinants in hepatitis $C$ virus infection. Genes Immun 2004, 5:237-245.

18. Singh R, Kaul R, Kaul A, Khan K: A comparative review of HLA associations with hepatitis B and C viral infections across global populations. World J Gastroenterol 2007, 13:1770-1787

19. Sheppard P, Kindsvogel W, Xu W, Henderson K, Schlutsmeyer S, Whitmore TE, Kuestner R, Garrigues U, Birks C, Roraback J, Ostrander C, Dong D, Shin J, Presnell S, Fox B, Haldeman B, Cooper E, Taft D, Gilbert T, Grant FJ, Tackett M, Krivan W, McKnight G, Clegg C, Foster D, Klucher KM: IL-28, IL-29 and their class II cytokine receptor IL-28R. Nat Immunol 2003, 4:63-68.

20. Ge D, Fellay J, Thompson AJ, Simon JS, Shianna KV, Urban TJ, Heinzen EL, Qiu P, Bertelsen AH, Muir AJ, Sulkowski M, McHutchison JG, Goldstein DB: Genetic variation in IL28B predicts hepatitis C treatment-induced viral clearance. Nature 2009, 461:399-401.

21. Suppiah V, Moldovan M, Ahlenstiel G, Berg T, Weltman M, Abate ML, Bassendine M, Spengler U, Dore GJ, Powell E, Riordan S, Sheridan D, Smedile A, Fragomeli V, Müller T, Bahlo M, Stewart G, Booth D, George J: IL28B is associated with response to chronic hepatitis $C$ interferon- $a$ and ribavirin therapy. Nat Genet 2009, 41:1100-1104.

22. Tanaka Y, Nishida N, Sugiyama M, Kurosaki M, Matsuura K, Sakamoto N, Nakagawa M, Korenaga M, Hino K, Hige S, Ito Y, Mita E, Tanaka E, Mochida S, Murawaki Y, Honda M, Sakai A, Hiasa Y, Nishiguchi S, Koike A, Sakaida I,
Imamura M, Ito K, Yano K, Masaki N, Sugauchi F, Izumi N, Tokunaga K, Mizokami M: Genome-wide association of $1 \mathrm{~L} 28 \mathrm{~B}$ with response to pegylated interferon- $\alpha$ and ribavirin therapy for chronic hepatitis $\mathrm{C}$. Nat Genet 2009, 41:1105-1109.

23. Conjeevaram HS, Fried MW, Jeffers LJ, Terrault NA, Wiley-Lucas TE, Afdhal N, Brown RS, Belle SH, Hoofnagle JH, Kleiner DE, Howell CD; Virahep-C Study Group: Peginterferon and ribavirin treatment in African American and Caucasian American patients with hepatitis C genotype 1. Gastroenterology 2006, 131:470-477.

24. MCCarthy JJ, Li JH, Thompson A, Suchindran S, Lao XQ, Patel K, Tillmann HL, Muir AJ, McHutchison JG: Replicated association between an IL28B gene variant and a sustained response to pegylated interferon and ribavirin. Gastroenterology 2010, 138:2307-2314.

25. Thompson AJ, Muir AJ, Sulkowski MS, Ge D, Fellay J, Shianna KV, Urban T, Afdhal NH, Jacobson IM, Esteban R, Poordad F, Lawitz EJ, McCone J, Shiffman ML, Galler GW, Lee WM, Reindollar R, King JW, Kwo PY, Ghalib RH, Freilich B, Nyberg LM, Zeuzem S, Poynard T, Vock DM, Pieper KS, Patel K, Tillmann HL, Noviello S, Koury K, et al.: Interleukin-28B polymorphism improves vira kinetics and is the strongest pretreatment predictor of sustained virologic response in genotype 1 hepatitis C virus. Gastroenterology 2010 139:120-129.

26. Mangia A, Thompson AJ, Santoro R, Piazzolla V, Tillmann HL, Patel K, Shianna KV, Mottola L, Petruzzellis D, Bacca D, Carretta V, Minerva N, Goldstein DB, MCHutchison JG: An IL28B polymorphism determines treatment response of hepatitis $C$ virus genotype 2 or 3 patients who do not achieve a rapid virologic response. Gastroenterology 2010, 139:821-827.e1.

27. Clausen LN, Weis N, Astvad K, Schonning K, Fenger M, Krarup H, Bukh J, Benfield T: Interleukin-28B polymorphisms are associated with hepatitis $C$ virus clearance and viral load in a HIV-1-infected cohort. J Viral Hepat 2010 in press

28. Pineda JA, Caruz A, Rivero A, Neukam K, Salas I, Camacho A, Palomares JC, Mira JA, Martínez A, Roldán C, de la Torre J, Macías J: Prediction of response to pegylated interferon plus ribavirin by IL28B gene variation in patients coinfected with HIV and hepatitis C virus. Clin Infect Dis 2010, 51:788-795.

29. Rallón NI, Naggie S, Benito JM, Medrano J, Restrepo C, Goldstein D, Shianna KV, Vispo E, Thompson A, McHutchison J, Soriano V: Association of a single nucleotide polymorphism near the interleukin-28B gene with response to hepatitis C therapy in HIV/hepatitis C virus-coinfected patients. AIDS 2010, 24:F23-F29.

30. Thomas DL, Thio CL, Martin MP, Qi Y, Ge D, O'Huigin C, Kidd J, Kidd K, Khakoo SI, Alexander G, Goedert JJ, Kirk GD, Donfield SM, Rosen HR, Tobler LH, Busch MP, McHutchison JG, Goldstein DB, Carrington M: Genetic variation in IL28B and spontaneous clearance of hepatitis C virus. Nature 2009, 461:798-801.

31. Montes-Cano MA, García-Lozano JR, Abad-Molina C, Torrecillas F, Torres A Lopez-Cortes LF, Núñez-Roldán A, González-Escribano MF: Interleukin-28B genetic variants and hepatitis virus infection by different viral genotypes. Hepatology 2010, 52:33-37.

32. Tillmann HL, Thompson AJ, Patel K, Wiese M, Tenckhoff H, Nischalke HD, Lokhnygina Y, Kullig U, Göbel U, Capka E, Wiegand J, Schiefke I, GüthoffW, Grüngreiff K, König I, Spengler U, McCarthy J, Shianna KV, Goldstein DB, McHutchison JG, Timm J, Nattermann J; German Anti-D Study Group: A polymorphism near IL28B is associated with spontaneous clearance of acute hepatitis C virus and jaundice. Gastroenterology 2010, 139:1586-1592.

33. Rauch A, Kutalik Z, Descombes P, Cai T, Di lulio J, Mueller T, Bochud M, Battegay M, Bernasconi E, Borovicka J, Colombo S, Cerny A, Dufour JF, Furrer H, Günthard HF, Heim M, Hirschel B, Malinverni R, Moradpour D, Müllhaupt B, Witteck A, Beckmann JS, Berg T, Bergmann S, Negro F, Telenti A, Bochud PY; Swiss Hepatitis C Cohort Study; Swiss HIV Cohort Study: Genetic variation in IL28B is associated with chronic hepatitis C and treatment failure: a genome-wide association study. Gastroenterology 2010, 138:1338-1345.

34. Marcello T, Grakoui A, Barba-Spaeth G, Machlin ES, Kotenko SV, MacDonald $M R$, Rice CM: Interferons $a$ and $\lambda$ inhibit hepatitis $C$ virus replication with distinct signal transduction and gene regulation kinetics. Gastroenterology 2006, 131:1887-1898.

35. Fellay J, Thompson AJ, Ge D, Gumbs CE, Urban TJ, Shianna KV, Little LD, Qiu P, Bertelsen AH, Watson M, Warner A, Muir AJ, Brass C, Albrecht J, Sulkowski M, McHutchison JG, Goldstein DB: ITPA gene variants protect against anaemia in patients treated for chronic hepatitis C. Nature 2010, 464:405-408.

36. Thompson AJ, Fellay J, Patel K, Tillmann HL, Naggie S, Ge D, Urban TJ, Shianna KV, Muir AJ, Fried MW, Afdhal NH, Goldstein DB, McHutchison JG: Variants in the ITPA gene protect against ribavirin-induced hemolytic anemia and 
decrease the need for ribavirin dose reduction. Gastroenterology 2010, 139:1181-1189.

37. Sakamoto N, Tanaka Y, Nakagawa M, Yatsuhashi H, Nishiguchi S, Enomoto N, Azuma S, Nishimura-Sakurai Y, Kakinuma S, Nishida N, Tokunaga K, Honda M, Ito K, Mizokami M, Watanabe M: ITPA gene variant protects against anemia induced by pegylated interferon- $a$ and ribavirin therapy for Japanese patients with chronic hepatitis C. Hepatol Res 2010, 40:1063-1071.

38. Ochi H, Maekawa T, Abe H, Hayashida Y, Nakano R, Kubo M, Tsunoda T, Hayes CN, Kumada H, Nakamura Y, Chayama K: ITPA polymorphism affects ribavirin-induced anemia and outcomes of therapy - a genome-wide study of Japanese HCV virus patients. Gastroenterology 2010, 139:1190-1197.

39. Pawlotsky JM, Pellerin M, Bouvier M, Roudot-Thoraval F, Germanidis G, Bastie A, Darthuy F, Remire J, Soussy CJ, Dhumeaux D: Genetic complexity of the hypervariable region 1 (HVR1) of hepatitis $\mathrm{C}$ virus (HCV): influence on the characteristics of the infection and responses to interferon a therapy in patients with chronic hepatitis C. J Med Virol 1998, 54:256-264.

40. Sarrazin C, Bruckner M, Herrmann E, Ruster B, Bruch K, Roth WK, Zeuzem S: Quasispecies heterogeneity of the carboxy-terminal part of the E2 gene including the PePHD and sensitivity of hepatitis $C$ virus $1 \mathrm{~b}$ isolates to antiviral therapy. Virology 2001, 289:150-163

41. Chambers TJ, Fan X, Droll DA, Hembrador E, Slater T, Nickells MW, Dustin LB, Dibisceglie AM: Quasispecies heterogeneity within the E1/E2 region as a pretreatment variable during pegylated interferon therapy of chronic hepatitis C virus infection. J Virol 2005, 79:3071-3083.

42. Moreau I, Levis J, Crosbie O, Kenny-Walsh E, Fanning LJ: Correlation between pre-treatment quasispecies complexity and treatment outcome in chronic HCV genotype 3a. Virol J 2008, 5:78.

43. Lopez-Labrador FX, Ampurdanes S, Gimenez-Barcons M, Guilera M, Costa J, Jimenez de Anta MT, Sanchez-Tapias JM, Rodes J, Saiz JC: Relationship of the genomic complexity of hepatitis $C$ virus with liver disease severity and response to interferon in patients with chronic HCV genotype $1 \mathrm{~b}$ infection [correction of interferon]. Hepatology 1999, 29:897-903.

44. Sandres K, Dubois M, Pasquier C, Payen JL, Alric L, Duffaut M, Vinel JP, Pascal JP, Puel J, Izopet J: Genetic heterogeneity of hypervariable region 1 of the hepatitis $\mathrm{C}$ virus (HCV) genome and sensitivity of $\mathrm{HCV}$ to a interferon therapy. J Virol 2000, 74:661-668.

45. Abbate I, Lo lacono O, Di Stefano R, Cappiello G, Girardi E, Longo R, Ferraro D, Antonucci G, Di Marco V, Solmone M, Craxì A, Ippolito G, Capobianchi MR: HVR-1 quasispecies modifications occur early and are correlated to initial but not sustained response in HCV-infected patients treated with pegylated- or standard-interferon and ribavirin. J Hepatol 2004, 40:831-836.

46. Farci P, Strazzera R, Alter HJ, Farci S, Degioannis D, Coiana A, Peddis G, Usai F, Serra G, Chessa L, Diaz G, Balestrieri A, Purcell RH: Early changes in hepatitis $C$ viral quasispecies during interferon therapy predict the therapeutic outcome. Proc Natl Acad Sci U S A 2002, 99:3081-3086.

47. Fan X, Mao Q, Zhou D, Lu Y, Xing J, Xu Y, Ray SC, Di Bisceglie AM: High diversity of hepatitis $C$ viral quasispecies is associated with early virological response in patients undergoing antiviral therapy. Hepatology 2009, 50:1765-1772

48. Enomoto N, Sakuma I, Asahina Y, Kurosaki M, Murakami T, Yamamoto C, Izumi $\mathrm{N}$, Marumo F, Sato C: Comparison of full-length sequences of interferonsensitive and resistant hepatitis $C$ virus $1 \mathrm{~b}$. Sensitivity to interferon is conferred by amino acid substitutions in the NS5A region. $J$ Clin Invest 1995, 96:224-230

49. Witherell GW, Beineke P: Statistical analysis of combined substitutions in nonstructural $5 \mathrm{~A}$ region of hepatitis $\mathrm{C}$ virus and interferon response. J Med Virol 2001, 63:8-16.

50. Pascu M, Martus P, Hohne M, Wiedenmann B, Hopf U, Schreier E, Berg T: Sustained virological response in hepatitis $C$ virus type $1 \mathrm{~b}$ infected patients is predicted by the number of mutations within the NS5A-ISDR: a meta-analysis focused on geographical differences. Gut 2004 53:1345-1351

51. Nakagawa M, Sakamoto N, Ueyama M, Mogushi K, Nagaie S, Itsui Y, Azuma S, Kakinuma S, Tanaka H, Enomoto N, Watanabe M: Mutations in the interferon sensitivity determining region and virological response to combination therapy with pegylated-interferon alpha $2 \mathrm{~b}$ plus ribavirin in patients with chronic hepatitis C-1b infection. J Gastroenterol 2010, 45:656-665.

52. Toyoda H, Kumada T, Kiriyama S, Tanikawa M, Hisanaga Y, Kanamori A, Tada T, Arakawa T, Fujimori M, Niinomi T, Ando N, Yasuda S, Sakai K, Kimura J: High ability to predict the treatment outcome of peginterferon and ribavirin combination therapy based on the reduction in HCV RNA levels at 4 weeks after starting therapy and amino acid substitutions in the hepatitis C virus in patients infected with HCV genotype 1b. J Gastroentero/ 2010, in press.

53. Mori N, Imamura M, Kawakami Y, Saneto H, Kawaoka T, Takaki S, Aikata H, Takahashi S, Chayama K: Randomized trial of high-dose interferon- $a-2 b$ combined with ribavirin in patients with chronic hepatitis $\mathrm{C}$ : correlation between amino acid substitutions in the core/NS5A region and virological response to interferon therapy. J Med Virol 2009, 81:640-649.

54. Kurbanov F, Tanaka Y, Matsuura K, Sugauchi F, Elkady A, Khan A, Hasegawa I, Ohno T, Tokuda H, Mizokami M: Positive selection of core $70 \mathrm{Q}$ variant genotype $1 \mathrm{~b}$ hepatitis $C$ virus strains induced by pegylated interferon and ribavirin. J Infect Dis 2010, 201:1663-1671.

55. Toyoda H, Kumada T, Tada T, Arakawa T, Hayashi K, Honda T, Katano Y, Goto H: Association between HCV amino acid substitutions and outcome of peginterferon and ribavirin combination therapy in HCV genotype $1 \mathrm{~b}$ and high viral load. $J$ Gastroenterol Hepatol 2010, 25:1072-1078

56. Akuta N, Suzuki F, Hirakawa M, Kawamura Y, Yatsuji H, Sezaki H, Suzuki Y, Hosaka T, Kobayashi M, Kobayashi M, Saitoh S, Arase Y, Ikeda K, Kumada H: Association of amino acid substitution pattern in core protein of hepatitis $C$ virus genotype 2 a high viral load and virological response to interferonribavirin combination therapy. Intervirology 2009, 52:301-309.

57. Hayes CN, Kobayashi M, Akuta N, Suzuki F, Kumada H, Abe H, Miki D, Imamura M, Ochi H, Kamatani N, Nakamura Y, Chayama K: HCV substitutions and IL28B polymorphisms on outcome of peg-interferon plus ribavirin combination therapy. Gut 2011, 60:261-267.

58. Akuta N, Suzuki F, Hirakawa M, Kawamura Y, Yatsuji H, Sezaki H, Suzuki Y, Hosaka T, Kobayashi M, Kobayashi M, Saitoh S, Arase Y, Ikeda K, Chayama K, Nakamura $\mathrm{Y}$, Kumada $\mathrm{H}$ : Amino acid substitution in hepatitis $\mathrm{C}$ virus core region and genetic variation near the interleukin $28 \mathrm{~B}$ gene predict viral response to telaprevir with peginterferon and ribavirin. Hepatology 2010, 52:421-429.

59. Saito T, Ito T, Ishiko H, Yonaha M, Morikawa K, Miyokawa A, Mitamura K Sequence analysis of PePHD within HCV E2 region and correlation with resistance of interferon therapy in Japanese patients infected with HCV genotypes 2a and 2b. Am J Gastroenterol 2003, 98:1377-1383.

60. Sarrazin C, Kornetzky I, Ruster B, Lee JH, Kronenberger B, Bruch K, Roth WK, Zeuzem S: Mutations within the E2 and NS5A protein in patients infected with hepatitis $C$ virus type $3 a$ and correlation with treatment response. Hepatology 2000, 31:1360-1370.

61. Hung CH, Lee CM, Lu SN, Lee JF, Wang JH, Tung HD, Chen TM, Hu TH, Chen WJ, Changchien CS: Mutations in the NS5A and E2-PePHD region of hepatitis $C$ virus type $1 \mathrm{~b}$ and correlation with the response to combination therapy with interferon and ribavirin. J Viral Hepat 2003, 10:87-94.

62. Watanabe H, Nagayama K, Enomoto N, Itakura J, Tanabe Y, Sato C, Izumi N, Watanabe M: Amino acid substitutions in PKR-elF2 phosphorylation homology domain (PePHD) of hepatitis $C$ virus $E 2$ protein in genotype $2 a / 2 b$ and $1 b$ in Japan and interferon efficacy. Hepatol Res 2003, 26:268-274.

63. Donlin MJ, Cannon NA, Yao E, Li J, Wahed A, Taylor MW, Belle SH, Di Bisceglie AM, Aurora R, Tavis JE: Pretreatment sequence diversity differences in the full-length hepatitis $C$ virus open reading frame correlate with early response to therapy. J Virol 2007, 81:8211-8224

64. Cannon NA, Donlin MJ, Fan X, Aurora R, Tavis JE: Hepatitis C virus diversity and evolution in the full open-reading frame during antiviral therapy. PLOS One 2008, 3:e2123.

65. Donlin MJ, Cannon NA, Aurora R, Li J, Wahed A, Di Bisceglie AM, Tavis JE: Contribution of genome-wide HCV genetic differences to outcome of interferon-based therapy in Caucasian American and African American patients. PLoS One 2010, 5:e9032.

66. Aurora R, Donlin MJ, Cannon NA, Tavis JE: Genome-wide hepatitis C virus amino acid covariance networks can predict response to antiviral therapy in humans. J Clin Invest 2009, 119:225-236.

67. Campo DS, Dimitrova Z, Mitchell RJ, Lara J, Khudyakov Y: Coordinated evolution of the hepatitis C virus. Proc Natl Acad Sci U S A 2008, 105:9685-9690.

68. Sarrazin C, Kieffer TL, Bartels D, Hanzelka B, Müh U, Welker M, Wincheringer D, Zhou Y, Chu HM, Lin C, Weegink C, Reesink H, Zeuzem S, Kwong AD: Dynamic hepatitis $C$ virus genotypic and phenotypic changes in patients treated with the protease inhibitor telaprevir. Gastroenterology 2007. 
132:1767-1777.

69. Kieffer TL, Sarrazin C, Miller JS, Welker MW, Forestier N, Reesink HW, Kwong $A D$, Zeuzem S: Telaprevir and pegylated interferon- $a-2 a$ inhibit wild-type and resistant genotype 1 hepatitis C virus replication in patients. Hepatology 2007, 46:631-639.

70. Susser S, Welsch C, Wang Y, Zettler M, Domingues FS, Karey U, Hughes E, Ralston R, Tong X, Herrmann E, Zeuzem S, Sarrazin C: Characterization of resistance to the protease inhibitor boceprevir in hepatitis $\mathrm{C}$ virus-infected patients. Hepatology 2009, 50:1709-1718.

71. Grant PM, Zolopa AR: The use of resistance testing in the management of HIV-1-infected patients. Curr Opin HIV AIDS 2009, 4:474-480

72. Si Ahmed SN, Zoulim F: Pathobiology of HBV mutants and clinical impact for treatment monitoring. Expert Rev Anti Infect Ther 2009, 7:309-320.

73. Kikuchi I, Ueda A, Mihara K, Miyanaga O, Machidori H, Ishikawa E, Tamura K: The effect of HLA alleles on response to interferon therapy in patients with chronic hepatitis C. Eur J Gastroenterol Hepatol 1998, 10:859-863.

74. Sim H, Wojcik J, Margulies M, Wade JA, Heathcote J: Response to interferon therapy: influence of human leucocyte antigen alleles in patients with chronic hepatitis C. J Viral Hepat 1998, 5:249-253.

75. Wawrzynowicz-Syczewska M, Underhill JA, Clare MA, Boron-Kaczmarska A, McFarlane IG, Donaldson PT: HLA class II genotypes associated with chronic hepatitis $C$ virus infection and response to alpha-interferon treatment in Poland. Liver 2000, 20:234-239.

76. Yu ML, Dai CY, Chen SC, Chiu CC, Lee LP, Lin ZY, Hsieh MY, Wang LY, Chuang WL, Chang WY: Human leukocyte antigen class I and II alleles and response to interferon-alpha treatment, in Taiwanese patients with chronic hepatitis C virus infection. J Infect Dis 2003, 188:62-65.

77. Zang GQ, Xi M, Feng ML, Ji Y, Yu YS, Tang ZH: Curative effects of interferon-a and HLA-DRB1-DQA1 and -DQB1 alleles in chronic viral hepatitis B. World J Gastroenterol 2004, 10:2116-2118

78. Jiao J, Wang JB: Hepatitis $C$ virus genotypes, HLA-DRB alleles and their response to interferon- $a$ and ribavirin in patients with chronic hepatitis $C$. Hepatobiliary Pancreat Dis Int 2005, 4:80-83.

79. Tseng KC, Chang CK, Chou AL, Hsieh YH, Tseng CA, Lai NS: Prognostic effect of human leukocyte antigen class I and II alleles on chronic hepatitis $C$ patients treated by pegylated interferon-a plus ribavirin in Taiwan. Hepatogastroenterology 2010, 57:456-461.

80. Ali L, Mansoor A, Ahmad N, Siddiqi S, Mazhar K, Muazzam AG, Qamar R, Khan KM: Patient HLA-DRB1* and -DQB1* allele and haplotype association with hepatitis C virus persistence and clearance. J Gen Virol 2010, 91:1931-1938.

81. Dai CY, Chuang WL, Hsieh MY, Huang JF, Lin YY, Chu PY, Hou NJ, Lin ZY, Chen SC, Hsieh MY, Wang LY, Yu ML: Human leukocyte antigen alleles and the response to pegylated interferon/ribavirin therapy in chronic hepatitis $C$ patients. Antiviral Res 2010, 85:396-402.

82. Carneiro VL, Lemaire DC, Bendicho MT, Souza SL, Cavalcante LN, Angelo AL, Freire SM, Mendes CM, Santana N, Lyra LG, Lyra AC: Natural killer cell receptor and HLA-C gene polymorphisms among patients with hepatitis $\mathrm{C}:$ a comparison between sustained virological responders and nonresponders. Liver Int 2010, 30:567-573.

83. Nattermann J, Vogel M, Berg T, Danta M, Axel B, Mayr C, Bruno R, Tural C, Klausen G, Clotet B, Lutz T, Grünhage F, Rausch M, Nischalke HD, Schewe K, Bienek B, Haerter G, Sauerbruch T, Rockstroh JK, Spengler U; Kompetenznetz HIV/AIDS: Effect of the interleukin-6 C174G gene polymorphism on treatment of acute and chronic hepatitis $\mathrm{C}$ in human immunodeficiency virus coinfected patients. Hepatology 2007, 46:1016-1025.

84. Edwards-Smith CJ, Jonsson JR, Purdie DM, Bansal A, Shorthouse C, Powell EE: Interleukin-10 promoter polymorphism predicts initial response of chronic hepatitis C to interferon alfa. Hepatology 1999, 30:526-530.

85. Yee LJ, Tang J, Gibson AW, Kimberly R, Van Leeuwen DJ, Kaslow RA: Interleukin 10 polymorphisms as predictors of sustained response in antiviral therapy for chronic hepatitis C infection. Hepatology 2001,
33:708-712.

86. Mueller T, Mas-Marques A, Sarrazin C, Wiese M, Halangk J, Witt H, Ahlenstiel G, Spengler U, Goebel U, Wiedenmann B, Schreier E, Berg T: Influence of interleukin 12B (IL12B) polymorphisms on spontaneous and treatmentinduced recovery from hepatitis C virus infection. $J$ Hepatol 2004, 41:652-658.

87. Hijikata M, Mishiro S, Miyamoto C, Furuichi Y, Hashimoto M, Ohta Y: Genetic polymorphism of the MxA gene promoter and interferon responsiveness of hepatitis C patients: revisited by analyzing two SNP sites (-123 and -88) in vivo and in vitro. Intervirology 2001, 44:379-382.

88. Ahlenstiel G, Berg T, Woitas RP, Grünhage F, Iwan A, Hess L, Brackmann HH, Kupfer B, Schernick A, Sauerbruch T, Spengler U: Effects of the CCR5-Delta32 mutation on antiviral treatment in chronic hepatitis C. J Hepatol 2003, 39:245-252.

89. Wasmuth HE, Werth A, Mueller T, Berg T, Dietrich CG, Geier A, Gartung C, Lorenzen J, Matern S, Lammert F: Haplotype-tagging RANTES gene variants influence response to antiviral therapy in chronic hepatitis C. Hepatology 2004, 40:327-334.

90. Nattermann J, Vogel M, Nischalke HD, Danta M, Ahlenstiel G, Michalk M, Sauerbruch T, Rockstroh JK, Spengler U: The transforming growth factor- $\beta$ high-producer genotype is associated with response to hepatitis $C$ virusspecific therapy in HIV-positive patients with acute hepatitis C. AIDS 2008, 22:1287-1292

91. Dai CY, Chuang WL, Chang WY, Chen SC, Lee LP, Hsieh MY, Hou NJ, Lin ZY, Huang JF, Hsieh MY, Wang LY, Yu ML: Tumor necrosis factor-a promoter polymorphism at position -308 predicts response to combination therapy in hepatitis C virus infection. J Infect Dis 2006, 193:98-101.

92. Huang $Y$, Yang H, Borg BB, Su X, Rhodes SL, Yang K, Tong X, Tang G, Howell CD, Rosen HR, Thio CL, Thomas DL, Alter HJ, Sapp RK, Liang TJ: A functional SNP of interferon- $\gamma$ gene is important for interferon- $a$-induced and spontaneous recovery from hepatitis C virus infection. Proc Natl Acad SC US A 2007, 104:985-990.

93. Naito M, Matsui A, Inao M, Nagoshi S, Nagano M, Ito N, Egashira T, Hashimoto M, Mishiro S, Mochida S, Fujiwara K: SNPs in the promoter region of the osteopontin gene as a marker predicting the efficacy of interferon-based therapies in patients with chronic hepatitis C. J Gastroenterol 2005, 40:381-388.

94. Sarrazin C, Berg T, Weich V, Mueller T, Frey UH, Zeuzem S, Gerken G, Roggendorf M, Siffert W: GNB3 C825T polymorphism and response to interferon- $\alpha$ /ribavirin treatment in patients with hepatitis $C$ virus genotype 1 (HCV-1) infection. J Hepatol 2005, 43:388-393.

95. Ahlenstiel G, Nischalke HD, Bueren K, Berg T, Vogel M, Biermer M, Grünhage F, Sauerbruch T, Rockstroh J, Spengler U, Nattermann J: The GNB3 C825T polymorphism affects response to $\mathrm{HCV}$ therapy with pegylated interferon in HCV/HIV co-infected but not in HCV mono-infected patients. J Hepatol 2007, 47:348-355.

96. Yee L, Perez KA, Tang J, Van Leeuwen DJ, Kaslow RA: Association of CTLA4 polymorphisms with sustained response to interferon and ribavirin therapy for chronic hepatitis C virus infection. J Infect Dis 2003, 187:1264-1271.

97. Schott E, Witt H, Hinrichsen H, Neumann K, Weich V, Bergk A, Halangk J, Müller T, Tinjala S, Puhl G, Neuhaus P, Wiedenmann B, Berg T: Genderdependent association of CTLA4 polymorphisms with resolution of hepatitis C virus infection. J Hepatol 2007, 46:372-380.

\section{doi:10.1186/gm222}

Cite this article as: Tavis JE, et al: Prospects for personalizing antiviral therapy for hepatitis C virus with pharmacogenetics. Genome Medicine 2011, 3:8. 